Logarušić Dejan*

UDK: 001.891

Review article

DOI: $10.5937 /$ ptp2102043L

Received:: 14.04.2021.

Approved on: 12.05.2021.

Pages: $43-53$

\title{
METHODOLOGICAL PRINCIPLES AS ELEMENTS OF SCIENTIFIC RESEARCH WORK
}

\begin{abstract}
The author considers methodology as a scientific discipline of a general character, which studies and analyzes phenomena from a scientific point of view by applying the principles of objectivity, reliability, systematic approach and precision.

The methodology of scientific work, gradually tested, helps one reach basic and relevant knowledge starting from basic ideas, by applying methods and research procedures, defining science and scientific research work, proving hypotheses, and all the way to the implementation and indicators in the application of an established scientific research project. Starting from basic ideas, using methods, through research procedures, defining science and scientific research work, proving hypotheses, all the way to the implementation and indicators in the use of an established scientific research project, the methodology has found its application in theory and science.
\end{abstract}

Keywords: Methodology, scientific research, hypothesis, social reality, conclusion.

\section{The methodology applied in science and research}

A scientific discipline of a general nature called Methodology can refer to individual scientific disciplines (law, sociology, economics, etc.), i.e. to study and analyze, from a scientific point of view, and enable the application

\footnotetext{
${ }^{*}$ LLD, Assistant Professor, The University of Business Academy in Novi Sad, The Faculty of Law for Commerce and Judiciary in Novi Sad, Serbia, e-mail: dejan.logarusic@pravni-fakultet.info
} 
of its methods to reliable logical and methodological conclusions and finding the true factual situation.

The study of methodology as a scientific discipline is necessary for subjects dealing with science, striving for scientific truth and logical-critical thought activity regarding procedures during scientific work, as well as the ways of selecting and using certain methods that will be used in scientific research.

Methodology is a young scientific discipline in the nomenclature of scientific disciplines with 60-70 years of independent existence. During this period, significant works in the field of methodological sciences were written in the largest countries of the world (USA and Russia). The founders of methodology as a science in our country and both general and legal methodology are Radomir Lukić (Lukić,1958, p. 5-7) and Vojin Milić (Milić,1965, p. 11-12), who analyzed the sociological method in his work Methodology in Sociology.

Scientists and researchers who are, professionally related to Methodology in the scientific research sphere, such as faculties and institutes (or mentors, team leaders, researchers) should popularize and improve, in whole or in certain areas, scientific methodology as a scientific discipline.

The methodology of scientific work, as a young and open science, being gradually presented in six systematized chapters, helps to reach the basic and relevant knowledge regarding this scientific discipline.

\section{Scientific work and research}

It is important to emphasize that in every important area of life and work such as lumber, metal, chemical, food industry, agriculture, mining, education and financial activities, even a longer stay in the plains or mountains, near the sea and lakes, in rocky areas, there are certain written and unwritten rules, standards, criteria and principles.

Scientific work is created by the sum of all methods of scientific research. Scientific research is carried out for the purpose of developing science, i.e. with the aim of achieving the best possible quality of scientific papers. It is necessary to follow the development of the methodology of scientific research, since the obtained results depend on the method applied. The progress of science would not exist if there was no scientific research, that is, all countries and their scientists must constantly invest in themselves and science. Investing in scientific research is investing in the future, same as investing in education. 
We can address issues related to education and the quality of knowledge of entrepreneurs with special reference to the continuous maintenance of a high level of acquired knowledge. The stability of the legal framework, the amount of tax liabilities, the existence of reliefs and the possibility of exemption, the execution of court decisions, the smooth flow of financial transactions, as well as the stability of the environment have a great impact on the development of the country's economy.

Therefore, investing in the education of people in general, raising and constantly improving their knowledge is a highly justified social goal. Programs that contribute to the achievement of this goal should (at least in part) receive public support and be offered as a public good, since maintaining a high quality of entrepreneurial knowledge contributes, among other things, to the overall development of society.

\section{Evaluation of scientific work}

Evaluation, i.e. validation of scientific work includes each individual part of the paper that contributes to the explanation of the topic and complements the issues to which the paper refers. The first part of the paper mainly defines the methodological framework of research, elaboration of the topic and basic parameters. The conclusions, i.e. the results of the research, tell what knowledge was gained during the research and what effects or results were achieved. Conclusions arise from a text or something that has been done and written, that is, they summarize the answers to the questions and hypothesis testing. The conclusion is a personal attitude that is presented logically, concisely, clearly and not too long. The conclusions can indicate a scientific contribution to a theory, practice and future research.

In the following text, we will explain on which methods the research will be based, i.e. methods that are adapted to the needs of the subject research should be used. In addition to generally accepted scientific methods, depending on the goal of research, normative and research knowledge is used, as well as comparative and other research methods.

For experimental work within the research, data available on the websites of research and scientific institutions in the field related to the topic, international and domestic legislation, as well as statistical data that refer to the phenomenon under study, are used. The scientific paper should be of optimal length for the topic that the author has set as the task of processing. The title should correspond to the text that follows as its content analysis. The paper should be legally and technically done according to the modern requirements 
of writing this type of contribution, i.e. as the technical development requires (Simić, 1997, p. 23-31).

The results of the research should indicate the premise that the experimental work was done using appropriate literature, with set goals and line of work. The results represent a significant analysis of previous knowledge about the phenomena in the tested given topic and the achieved degree of applicability, as well as the author's conclusions reached by the research.

The abstract is composed in at least two languages, Serbian and English for example, then the key words are defined followed by parts of the paper from the introduction, elaboration, conclusion and literature, and all sections should be filled in correctly, with the content of the paper comprises of theoretical definition of issues and professional analysis of data obtained by mini-research, which should meet the need to consider the basic issues related to the topic.

The way of writing and the author's language should be clear, precise and concrete. The use of literature should be methodologically correct, which depends on the scope of research, i.e. if the research is more extensive the author should take a larger and broader fund of literature as a theoretical basis, which would allow him to make an analysis of other authors' opinions and make a short analysis of some of the typical solutions in comparative legislation.

The final evaluation of the research should point out that the paper was written in accordance with the explanation given in the topic application, that it contains all important elements and that it is an original contribution to science as the paper contains unique conclusions about the phenomenon under consideration and special views on the given topic, effects achieved and their mutual influences, i.e. improvements of research methods and achieving a higher degree in solving individual specific cases.

\section{The truthfulness of scientific research}

Scientific research that encompasses a special part of reality, i.e. social reality in which human being is both an object and a subject of research, makes research more socially complex and difficult than in the analysis and research of natural areas and parts of that reality.

In order to adequately, comprehensively, validly and objectively reach the knowledge of social reality, research of social phenomena should have special ways and possibilities of overcoming the contradictions between subjects and objects of research, i.e. the possibility to achieve unity of historical and logical knowledge and opinion. In research, science uses principles that differentiate between scientific knowledge from those acquired on the basis 
of common sense, especially in cases of studying social phenomena, relationships and processes.

\section{Principles of scientific research work}

The term principle, in accordance with many scientific theories, denotes basic and initial learning, beginning, source, cause, foundation and basic thought. Thus generally accepted concepts in science are called basic concepts or theories, from which certain conclusions and wide generalizations can be drawn (Lukić,1963, p. 464-466).

In addition to the many principles of scientific research that are mentioned, the most important are those with scientific agreement regarding their relevance:

1) The principle of objectivity

2) The principle of reliability

3) The principle of systematicity and

4) The principle of precision

We should also consider the relationship of observation according to the principles, i.e. scientific tenets as rules and steps of the procedure of objectivity, systematicity and reliability, such as issues of theoretical orientation, validity, generality and precision, which we will omit in this observation, i.e. we will not consider their effects.

Observation as a research procedure in research applies different divisions and the application of quantitative and qualitative methods and their real but also overemphasized epistemological differences. Overemphasis is associated with the dominance of empiricism in sociology, that is, empiricism is a consequence of the interests of broader social groups and narrower interests within the scientific community.

The necessity of methodological design and research application of observation understood as an integrated procedure is argued by its subversive character, its objectivity and social changes that require the application of observation as a research procedure.

\section{Objectivity of scientific knowledge}

Objectivity is based on the general ontological-epistemological assumption that reality exists independently of the subject of scientific knowledge, i.e. regardless of a particular researcher and their personal attitudes or possible social prejudices, stereotypes, as well as possible individual 
and social interests and motives. By pointing out the principled impartiality, the universality and truthfulness of scientific knowledge are respected, as a basic and constitutive rule without which there would be no scientific activity.

In order to achieve a higher degree of objectivity, additional rationally critical and other relevant available experiential data will be included.

The possibilities of coming to new facts should be constantly and continuously researched, and in order for the factual situation to be correctly determined in the procedure, those should be tested and critically evaluated. The most important for scientific knowledge is that researchers are guided by the view that there is no forever undoubted and valid knowledge, in other words, objective and true knowledge must be based not only on accurate empirically verifiable data, but these verified data must be as complete as possible to cover the whole matter.

There are many wrong and one-sided interpretations of the notion of scientific objectivity. There is a secular and simplified understanding of scientific objectivity, according to which, the objectivity of scientific knowledge is reduced to determining only what can be observed (perceived) on the apparent level of reality, and it represents a common-sense understanding of objectivity. The objectivity of scientific knowledge does not mean that in the study of reality science remains on the surface of knowledge.

In fact, science always strives to mentally encompass some deeper, basic, essential, numerous, general and universal elements of the matter it studies, which most often cannot be directly observed and thus found out, but the investigation should be used in order to find certain causal relations and scientific laws of such occurrence.

More often, the principle of objectivity of scientific knowledge is misinterpreted, as a passive observational attitude towards reality. Without the active attitude of the researcher, there is no intellectual knowledge, that is, the researcher must strive for objective knowledge, so that their subjective attitude does not violate the essence of objectivity. Therefore the scientific methods that scientific researcher uses when researching objective realities.

In fact, objectivity is a reality, a truth that is not a thought but a reality existing independently of any subject and the subjective thoughts and interests of the subjects, valid for all rational beings; objectivity is universally valid and impartial (Vujaklija,1974, p. 633). 


\section{Reliability and validity of scientific knowledge}

The principle of reliability could be characterized as a link between the principle of objectivity and the principle of systematicity in science. It is most often connected with the principle of objectivity of scientific knowledge, especially with the requirement that every attitude in science must be directly or indirectly verifiable. Unlike knowledge based on common sense, which has a certain degree of objectivity and the possibility of empirical verification, scientific knowledge must encompass reliable, i.e. proven knowledge explained in a certain way. Scientific knowledge has value if it is valid (reliable). The reliability of new knowledge in scientific research is especially presented and especially valued when this knowledge is opposed to psychological persuasiveness and subjective attitude based on common sense of subjective and untested knowledge. Unlike unsystematic and unconvincing reasoning characterized by knowledge based on common sense, attitudes and certainty in science are accepted only if they result from systematically verified knowledge and logically correct reasoning.

Knowledge obtained on the basis of common sense is an exclusive knowledge that feels final, secure and certain, despite the fact that it is unverified and unproven. Scientific knowledge is, in principle, always uncertain, subject to doubt and is always relative due to its time-changing character. Scientific knowledge, despite the fact that it is based on a broad foundation of the experience-based, verified and systematically related data and information on actual reality, which are logically and theoretically correctly determined, is constantly being analyzed. Scientific knowledge is subject to constant verification, that is, this principle originates from the Siècle des Lumières in France and is expressed in the well-known Descartes' phrase "Cogito ergo sum" (I think therefore I exist).

Reliable knowledge is the knowledge which has been previously verified and by that verification, at least in part, confirmed. With reliable knowledge, the criteria of objectivity must first be met. Only what is objective deserves to be reliable and in a certain way verifiable, if not directly by the proposed methods then indirectly, by auxiliary methods of verification.

The scope of knowledge whose objective basis cannot be verified and confirmed such as religious knowledge and metaphysical attitudes that cannot be empirically verified, with the evaluation of the fact that experience is irrelevant to them, does not belong to the field of science and their reliability is not challenged; it can be stated a priori that this knowledge is completely unreliable. 
The answer to the way to achieve a higher degree of reliability in the process of scientific research can be found in three elementary ways, namely by testing each statement, hypothesis, attitude and theory in practical life, by increasing the quality of logical reasoning of statements, hypotheses, attitudes and theories and finally by indirect study and applying a wider range of theoretical conclusions in historical social practice. However, absolute exclusivity in the requirement to verify each statement, even when it comes to fundamental research, through empiricism, can lead the researcher to the path of extreme empiricism that is able to restrain the necessary measure of scientific originality, authenticity of the researcher's spirit, imagination and creativity which reduces the relevance of the scientific research project (Kozić,1996, p. 71). Certainly, the richer experience of a scientific research character, the breadth of conceptual-theoretical notions of reducing the difference from extreme empiricism contributes positively to the achievement of a higher degree of reliability.

\section{Systematic nature of scientific knowledge}

Systematicity as a universal scientific principle implies coherence with consistency and not contradiction of the order and priorities of thoughts and statements; in other words, the necessity as a universal scientific principle strives to connect statements into one ordered and logical and not contradictory whole.

In any research or definition, it is necessary to pay attention to the decisive facts and define the classification criteria, as well as to define identical, related, similar, opposite and opposing or merely different factors of the phenomenon or phenomena and to establishing a scientific system of consistency, especially when it comes to concepts and their statements.

The systematic nature of knowledge in the theoretical sciences is visibly manifested in the characteristics of their conceptual network and thought expression, but they find their most complete expression in scientific laws and theories, which arise from established causal relations.

Science is a complete system of knowledge that can be functionally or causally connected, i.e. every fact, law, theory, etc., which researchers come across during research must be connected with the system of science, i.e. in connection with the overall scientific knowledge, in order to eliminate any contradictions and confusions.

The intensity of social changes at the international and national level is very high; what was, in the not so distant past, defined by objective scientific 
truth, now cannot withstand the test of time or methodological procedures and techniques in present times and as such turns out to be wrong. I other words, objectivity recedes in the sphere of relativity from the point of view of the time dimension, i.e. duration.

One of the basic principles of science is that it must be objective, but if we are guided by the sole principle of objectivity, we must conclude that it is also partly relative or impermanent if we observe a certain social dynamics, which leads to the conclusion that scientific knowledge is objective, since it is in constant contact and correspondence with objective reality; but scientific knowledge is also relative because that correspondence is never complete, but always partial and approximate (Pešić,1999, p. 5).

Scientific knowledge is constantly being checked, since science strives for research and proof, while the appearance of new knowledge causes a wave of hesitation and doubt. Doubting the truth of something is a good way to compare and find the legal truth.

It is not easy to achieve objectivity when studying social reality. This is confirmed by the fact that traditional notions, various social, cultural (Šipovac et al., 2019, p. 105-116), local and group prejudices and stereotypes make it difficult and are set against taking an objective stand.

\section{Conclusion}

Methodology is basic,scientific discipline a general character. Scientific knowledge is constantly being checked i.e. methodology is a objectiv scientific discipline which uses methods and procedures in coming to scientific knowledge. Science is complet system of knowledge that can be functionally or causally connected. The contribution of the Methodology of scientific research work is that with its metods and principles (the principle of objectivity, the principle of reliability, the principle of sistematicity, and the principle of precision) as steps of the research process, it contributes to the development of other sciences,i.e. basic research contributes to the development of science in general. The author trying to emphasize the importance of methodology as a science which, with its research methods and tehniques, contributes to the application of fundamental research knowledge. 


\section{Logarušić Dejan}

Doktor pravnih nauka, docent, Univerzitet Privredna akademija u Novom Sadu, Pravni fakultet za privredu i pravosuđe u Novom Sadu, Srbija

\section{METODOLOŠKI PRINCIPI KAO ELEMENTI NAUČNO-ISTRAŽIVAČKOG RADA}

REZIME: Autor u radu razmatra metodologiju kao naučnu disciplinu opšteg karaktera, koja sa naučnog stanovišta izučava i analizira pojave primenom principa objektivnosti, pouzdanosti, sistematičnosti i preciznosti.

Metodologija naučnog rada, postupno testirana, pomaže da se dođe do osnovnog i relevantnog znanja polazeći od osnovnih ideja, primenom metoda, preko istraživačkih postupaka, definisanja nauke i naučno-istraživačkog rada, dokazivanjem hipoteza pa sve do implementacije i indikatora u sprovođenju utvrđenog naučno-istraživačkog projekta. Polazeći od osnovnih ideja, korišćenjem metoda, preko istraživačkih postupaka, definisanja nauke i naučno-istraživačkog rada, dokazivanjem hipoteza pa sve do implementacije i indikatora u sprovođenju utvrđenog naučno-istraživačkog projekta metodologija je našla svoju primenu u teoriji i nauci.

Ključne reči: metodologija, naučno istraživanje, hipoteza, društvena stvarnost, zaključak.

\section{References}

1. Kozić, P. (1996). Metodologija naučnoistraživačkog rada [Methodology of scientific research work]. Beograd: Univerzitet Braća Karić

2. Lukić, R. (1958). Teorija prava [Theory of Law]. Beograd: Naučna knjiga

3. Lukić, R. (1963). Terminološki i stvarni problemi u vezi sa pojmom pravo, [Terminological and real problems related to the term law]. Anali Pravnog fakulteta u Beogradu, (3/4), pp. 464-468

4. Milić, V. (1965). Sociološki metod [Sociological method]. Beograd: Nolit

5. Pešić, M. (1999). Sociologija [Sociology]. Beograd: IPS

6. Simić, D. (1997). Metodologija nauke i tehnički razvoj [Methodology of science and technical development]. Kragujevac: DSP-mecatronic 
7. Šipovac, R., Logarušić, D. \& Šipovac, V. (2019.) Ekonomski i socijalni efekti poreza na imovinu, [Economic and social effects of prpoerty tax]. Pravni život, 68 (11), pp. 103-114

8. Vujaklija, M. (1974). Leksikon stranih reči i izraza, [Lexicon of foreign words and expressions]. Beograd: Prosveta 